\title{
Autonomy and network modulation of photosynthesis and water relations of Coffea arabica in the field
}

\author{
Lívia H.G. de Camargo-Bortolin ${ }^{1}$, Carlos H.B. A. Prado ${ }^{1 *}$, Gustavo M. Souza ${ }^{2}$ and Paula Novaes $^{1}$ \\ ${ }^{1}$ Departamento de Botânica, Universidade Federal de São Carlos, 13565-905 São Carlos, SP, Brazil. ${ }^{2}$ Laboratório de \\ Ecofisiologia Vegetal, Universidade do Oeste Paulista, 19067-17, Presidente Prudente, SP, Brazil. *Corresponding \\ author: prado_chba@yahoo.com.br. Fax: +55-16-33518308; Tel.: +55-16-33518385
}

Received: 15 January 2008; Returned for revision: 23 February 2008; Accepted: 30 June 2008

The degree of connection between leaf gas exchange and leaf water potential, and the autonomy of these variables in relation to meteorological conditions were determined in three cultivars of Coffea arabica during clear and cloudy days. High values of vapor pressure deficit, air temperature and photosynthetic photon flux density resulted in low leaf autonomy during a clear day, irrespective the degree of connection among leaf physiological variables. Tight synchronization between physiological and meteorological variables was considered one important cause of net photosynthesis $\left(P_{\mathrm{N}}\right)$ decreasing during a clear day. In contrast, diurnal $P_{\mathrm{N}}$ was around three times higher on a cloudy day, when all cultivars presented high autonomy. Principal component analyses corroborated autonomy results revealing unambiguous opposition between leaf physiological and meteorological vectors, besides less leaf physiological variability throughout the clear day. Despite these general responses during clear and cloudy days, there were significant differences among studied cultivars. Leaf autonomy was an important reference to evaluate C. arabica under environmental stress and should be taken into account when selecting cultivars under field conditions.

Key words: Coffea canephora, connectance degree, daily net photosynthesis, system analysis, water stress

\begin{abstract}
Autonomia e modulação da rede da fotossíntese e das relações hídricas de Coffea arabica em condições de campo: O grau de conexão entre as trocas gasosas e o potencial hídrico foliar e a autonomia dessas variáveis em relação às condições meteorológicas foram determinados em Coffea arabica, ao longo de dias claros e nublados. Os valores elevados do déficit de pressão de vapor, da temperatura do ar e da densidade do fluxo de fótons fotossinteticamente ativos resultaram em reduzida autonomia no dia claro, independentemente do grau de conexão entre as variáveis fisiológicas foliares. A forte sincronização entre a fisiologia da folha e as variáveis meteorológicas foi considerada uma importante causa da diminuição da fotossíntese líquida $\left(P_{\mathrm{N}}\right)$ no dia claro. Por outro lado, o valor de $P_{\mathrm{N}}$ foi cerca de três vezes maior no dia nublado, quando todos os cultivares apresentaram maior autonomia. A análise de componentes principais corroborou os resultados de autonomia, revelando uma clara oposição entre os vetores fisiológicos e meteorológicos, além de uma menor variabilidade das características fisiológicas da folha ao longo do dia claro. Apesar dessas respostas gerais, ocorreram diferenças significativas entre as cultivares nos dias claro e nublado. A autonomia da folha foi uma importante referência para avaliar o comportamento de C. arabica sob estresse e deve ser levada em consideração na seleção de cultivares sob condições de campo.
\end{abstract}

Palavras-chave: análise sistêmica, Coffea canephora, estresse hídrico, grau de conectância, fotossíntese líquida diurna

\section{INTRODUCTION}

A rainy period is frequently associated with a high irradiance budget and high air and leaf temperatures in areas covered by Coffea arabica plantations in Brazil. In the field, high irradiance impairs net carbon assimilation
$\left(P_{\mathrm{N}}\right)$ of C. arabica lowering the potential efficiency of photosystem II and stomatal conductance to water vapor (Ronquim et al., 2006). Coffea arabica is native to high altitudes with a mild tropical climate, but $C$. canephora originates from hot tropical regions. Coffea arabica 
grafted onto C. canephora as rootstock often shows improved growth and grain yield, a phenomenon that has been associated with the higher capacity of $C$. canephora in absorbing water and nutrients (Fahl et al., 2001) as well as the resistance of this species to nematodes (Costa et al., 1991). Since C. canephora is more tolerant to high air temperature and soil water stress (Carelli et al., 1999) than C. arabica, a different behavior of leaf gas exchange and leaf water potential is thus to be expected on comparing non-grafted and grafted $C$. arabica. Therefore, substantial changes in the plantenvironment relationship can occur depending on the graft condition of $C$. arabica, leading to significant differences in grain productivity.

The interaction among leaf physiological variables and their relationship with the environment can be evaluated by autonomy and global connectance (Souza et al., 2005). Autonomy (At) depicts how much physiological variables change independently of the environment. Autonomy is determined by means of the correlation between physiological variables composing a given network and environmental variables affecting the network. From At values it is possible to estimate to what extent physiological variables are synchronized with environmental changes. Global connectance $(\mathrm{Cg})$ represents the degree that network components are connected to each other. It is determined through the correlation between network components with a close physiological relationship (Amzallag, 2001; Souza et al., 2005). High Cg of a given network results in prompt response to environmental disturbances, but it facilitates the propagation of disturbance through the network. In contrast, physiological networks with a reduced $\mathrm{Cg}$ among components tend to diminish disturbance propagation. In this study, Cg and At of a network composed by leaf gas exchange and leaf water potential were determined in three non-grafted and grafted $C$. arabica cultivars during the diurnal course during a rainy period in southeast Brazil. Alterations in $\mathrm{Cg}$ and At represented the modulation of a network under changing natural meteorological conditions during the course of clear and cloudy days under field conditions.

The ultimate goal here was to reveal new references for selecting non-grafted and grafted C. arabica cultivars capable of overcoming environmental stresses such as high irradiance, air temperature and vapor pressure deficit. Our hypothesis is that autonomy and connectance, together or apart, are suitable to evaluate the ability of $C$. arabica cultivars to maintain their carbon balance as positive as possible under contrasting daily meteorological conditions. Variables related to each other such as leaf gas exchange and leaf water potential were analyzed simultaneously, and the strength of connection between them was determined in a changing environment. In brief, using system analyses of leaf physiology we aimed to determine how and to what extent non-grafted and grafted $C$. arabica cultivars are able to overcome daily high atmospheric evaporative demand, excessive irradiance, and high air temperature.

\section{MATERIALS AND METHODS}

Area and period of study, climate conditions during measurements and plant materials: The experiment was carried out near the city of São Carlos (2202'15's, 47046'57',W, $957 \mathrm{~m}$ a.s.l.), southeast Brazil. Meteorological and leaf physiological data were obtained on a clear day on the $8^{\text {th }}$ of March 2002 and on a cloudy day on the $18^{\text {th }}$ of March 2003. The regional climate is tropical with a dry period during winter and part of spring (June-September) followed by a wet period during summer and part of autumn (October-March). Following the Koeppen climatic classification, the climate of the study area is between Aw and Cwa. According to a meteorological station located $12 \mathrm{~km}$ from the experimental site, total rainfall in March 2002 or 2003 was about $100 \mathrm{~mm}$, and total hours of bright sunshine during measurements was 6.0 on clear and 2.1 on cloudy days.

Non-grafted and grafted cultivars of Coffea arabica L. (Rubiaceae) utilized for determining physiological variables were planted in 1997. Coffea canephora Pierre ex. Froehner (Rubiaceae) genotype Apoatã (IAC 2258) was the rootstock used in grafted plants. Non-grafted and grafted C. arabica cultivars Catuaí Vermelho (IAC 81), Icatu Amarelo (IAC 2944), and Obatã (IAC 1669-20) were utilized in this study. Plant materials came from the Instituto Agronômico, Campinas, São Paulo State, Brazil. The distance between plants was $3.5 \mathrm{~m}$ x $1.0 \mathrm{~m}$. The plantation was maintained following commercial practices recommended by IAC. 
Leaf gas exchange, leaf water potential and micrometeorological measurements during clear and cloudy days: Data of diurnal leaf gas exchange were obtained using a portable infra-red gas analyzer (model LCA-4, ADC, Hodesddon, UK), connected to a Parkinson leaf chamber PLCN-4 (ADC). Leaf chamber temperature was set to track ambient air temperature $\left(\mathrm{T}_{\text {air }}\right)$ by means of a Peltier system attached to the head of PLCN-4 during diurnal courses. Leaf temperature $\left(\mathrm{T}_{\text {leaf }}\right)$ was determined by a copper-constantan thermocouple attached to PLCN-4. Photosynthetic photon flux density (PPFD) was measured through a quantum sensor on PLCN-4. The equipment operated as an open system determining net photosynthesis $\left(\mathrm{P}_{\mathrm{N}}\right)$, leaf transpiration $(\mathrm{E})$, stomatal conductance to water vapor $\left(\mathrm{g}_{\mathrm{s}}\right)$, and leaf intercellular $\left(\mathrm{C}_{\mathrm{i}}\right)$ and external $\left(\mathrm{C}_{\mathrm{e}}\right) \mathrm{CO}_{2}$ concentrations. Instantaneous transpiration efficiency (ITE) was calculated as $\mathrm{P}_{\mathrm{N}} / \mathrm{E}$ (Nogueira et al., 2004).

All individuals were adult and in good sanitary conditions with similar height and development in the field. Two individuals $7 \mathrm{~m}$ apart and far from the border of the plantation were chosen for each graft treatment and cultivar. Two plagiotropic branches directly exposed to solar irradiance in the upper third part of the canopy were chosen for each plant. Two completely expanded and healthy sunleaves were selected on each branch, usually the third leaf pair from the branch apex. Leaf gas exchange, $\mathrm{T}_{\text {leaf }}$, and PPFD were measured at about two hours intervals, from 0700 $\mathrm{h}$ to $1730 \mathrm{~h}$. Leaf water potential $\left(\Psi_{\mathrm{w}}\right)$ was obtained using a pressure chamber (model 3005, Soil Moisture, Santa Barbara, USA) immediately after leaf gas exchange determinations. The leaves used for determining $\Psi_{w}$ were chosen following the same criteria utilized in leaf gas exchange measurements. Air temperature and air relative humidity were monitored by LCA-4 with an open PLCN-4 in the shade and without a leaf before leaf gas exchange determinations.

Net photosynthesis as a function of photosynthetic photon flux density (PPFD): Curves $\left(P_{\mathrm{N}}\right.$-PPFD) were carried out at a favorable daytime for plant $\mathrm{CO}_{2}$ assimilation (from $0700 \mathrm{~h}$ to $0900 \mathrm{~h}$ ) under field conditions during the rainy period between 01 and 26 March 2002. These curves were obtained using the LCA-4 and PLCN-4 chamber described previously. The PLCN-4 chamber was connected to a PLU-002 light source (ADC) fitted with a halogen dichroic lamp (12 V, 20 $\mathrm{W}$ ). The leaf temperature was maintained by a Peltier system at ambient temperature $\left(25 \pm 0.5^{\circ} \mathrm{C}\right)$ during $P_{\mathrm{N}}$ measurements.
Different PPFDs (between 800-2000 $\mu \mathrm{mol} \mathrm{m} \mathrm{m}^{-2} \mathrm{~s}^{-1}$ ) were obtained by controlling the voltage applied on PLU-002. Values of PPFD below $800 \mu \mathrm{mol} \mathrm{m} \mathrm{m}^{-2} \mathrm{~s}^{-1}$ were obtained by reducing the voltage on PLU-002 and fitting neutral glass filters (Comar Instruments, Cambridge, UK) between the leaf and light source. Two non-grafted and two grafted plants were used to construct $P_{\mathrm{N}}$-PPFD curves. Two completely expanded and healthy sun-leaves on plagiotropic branches were chosen in the superior third part of the canopy from each plant. Two $P_{\mathrm{N}}$-PPFD curves in each treatment (nongrafted and grafted) were obtained for each cultivar. Both corresponding $P_{\mathrm{N}}$-PPFD curves were merged and adjusted using equation I described by Prado and Moraes (1997). The value of PPFD when $P_{\mathrm{N}}$ achieved $90 \%$ of maximum net photosynthesis was designated the light saturation point $\left(\mathrm{L}_{\mathrm{s}}, \mu \mathrm{mol} \mathrm{m} \mathrm{m}^{-2} \mathrm{~s}^{-1}\right)$.

$$
P_{\mathrm{N}}=P_{\mathrm{Nma}} \mathrm{x}\left(1-\mathrm{e}^{-k(P P F D-L C)}\right)
$$

where $P_{\mathrm{N} \max }$ is the maximum $P_{\mathrm{N}}\left(\mu \mathrm{mol} \mathrm{m} \mathrm{m}^{-2} \mathrm{~s}^{-1}\right), \mathrm{k}$ is a constant of proportionality, and Lc is the light compensation point.

Integrated value of $P_{N}$ from the diurnal course and the potential and actual $P_{N}$ on daily basis: Values of $P_{\mathrm{N}}$ obtained during the diurnal course were integrated using equation II, which generated the corresponding integrated value of $\mathrm{P}_{\mathrm{N}}$ along the day $\left(\mathrm{IP}_{\mathrm{N}}\right)$ as described by Kikusawa et al. (2004) and Ronquim et al. (2006):

$$
\mathrm{I} P_{\mathrm{N}}=\int \mathrm{f}(x) \mathrm{d}(x)
$$

where $x$ is the time interval in seconds along the day (independent variable); $\mathrm{f}(x)$ is the dependent variable $P_{\mathrm{N}}$, and $\mathrm{d}(x)$ is the derived time interval in seconds.

Two integrated $P_{\mathrm{N}}\left(P_{\mathrm{N}}\right.$ per day) were calculated for each diurnal course, together with potential $\left(\mathrm{PDP}_{\mathrm{N}}\right)$ and actual $\left(\mathrm{ADP} P_{\mathrm{N}}\right.$ ) daily net assimilations. Potential $P_{\mathrm{N}}$ was calculated in two steps: $P_{\mathrm{Nmax}}$ (from equation I) and the values of PPFD obtained during the course of the day were initially applied in equation I for determining the expected $P_{\mathrm{N}}$ at each time of the day; equation II was used subsequently to integrate these predicted $P_{\mathrm{N}}$ values throughout the day, resulting in integrated daily $\mathrm{PDP} P_{\mathrm{N}}$. This variable represents the daily net assimilation eventually limited by low PPFD during the course of the day. The integrated daily $\operatorname{ADP} P_{\mathrm{N}}$ was calculated using $P_{\mathrm{N}}$ measured during the course of the day applied directly to equation II. Daily $\mathrm{AD} P_{\mathrm{N}}$ represents the daily net assimilation limited by ambient and internal plant 
constraints such as high VPD air and low $\Psi_{\text {w }}$, respectively. Comparing both $\mathrm{PDP} P_{\mathrm{N}}$ and $\mathrm{ADP} P_{\mathrm{N}}$, it was possible to estimate the extent to which net $\mathrm{CO}_{2}$ assimilation declined in non-grafted and grafted plants of each cultivar as a function of environmental and internal plant constraints during the course of the day (Kikusawa et al., 2004; Ronquim et al., 2006).

Connectance, autonomy, and principal component analysis: The normality of each physiological and meteorological mean data set obtained throughout the diurnal courses was tested before applying the Pearson correlation coefficient for calculating connectance and autonomy. The Jarque-Bera normality test (Zar, 1999) was applied on each set of variables. All data sets presented normal distribution. Therefore, it was possible to obtain the Pearson correlation coefficient from any paired variables throughout the diurnal courses, utilizing this coefficient in subsequent connectance and autonomy determinations.

The modulation of leaf photosynthesis network was assessed using the concept of global connectance, $\mathrm{Cg}$ (Amzallag, 2001). The Pearson correlation coefficient ( $r$ ) obtained for each paired variable in the leaf physiological network was used to determine the strength of the relationship (connection) between physiological variables. Subsequently, $r$-values were normalized by $z$ transformation, becoming $z$-values (the connectance values) as indicated by Amzallag (2001):

$$
z=0.5 \ln \left[\frac{(1+|r|)}{(1-|r|)}\right]
$$

Network global connectance $(\mathrm{Cg})$ was represented by the average of $z$-values (Amzallag, 2001):

$$
C g=\frac{1}{m}\left[z\left(A, X_{1}\right)+\ldots+z\left(A, X_{m}\right)\right]
$$

Figure 1 shows the topology of the proposed leaf physiological network resulting in a similar design to that proposed by Prado et al. (2004). Above the physiological network there are meteorological variables related to the strength of connection between paired physiological variables during the course of the day. Plant autonomy (At) was obtained through the correlation between leaf physiological variables and the meteorological variables (Souza et al., 2004; Souza et al., 2005). Therefore, At was determined on clear and cloudy days as the average of $z$ values between two data sets: $P_{\mathrm{N}}, g_{\mathrm{s}}, C_{\mathrm{i}} / C_{\mathrm{e}}, E, \mathrm{ITE}, \mathrm{Y}_{\mathrm{w}}$, $\mathrm{T}_{\text {leaf }}$, and PPFD, $\mathrm{T}_{\text {air }}, \mathrm{VPD}_{\text {air }}$. Thus, lower connectance between physiological-meteorological variables means a higher degree of autonomy (Souza et al., 2005).

The principal component analysis (PCA) was accomplished using the PC-ORD software, version 3.12, MJM Software Design (Gleneden Beach, Oregon, USA). Each one of the two axes of the PCA graph (pc1 and pc2) was denominated the principal component based on the correlations among analyzed variables. Therefore, the PCA graph allowed the analysis of all physiological and meteorological variables in a two-dimensional space guided by two axes (pc1 and pc2). The vectors of PCA represented the more important physiological or meteorological variables determining the distribution of symbols on quadrants (Manly, 1994).

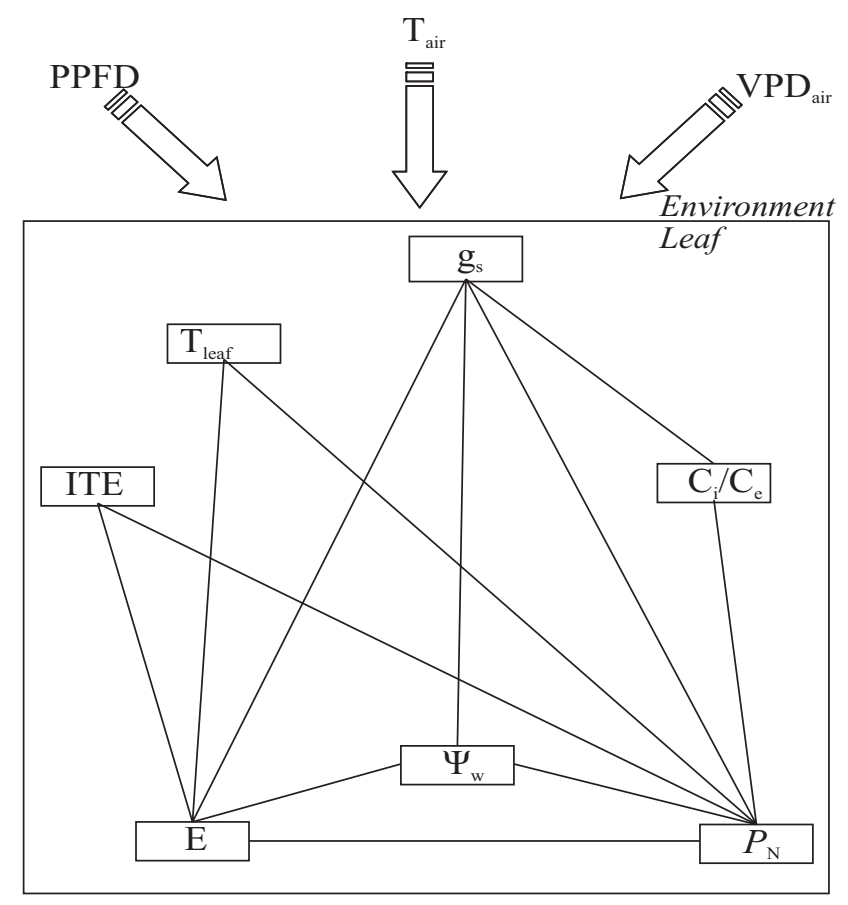

Figure 1. Topology of a network representing the interactions of leaf gas exchange and leaf water potential $\left(\Psi_{w}\right)$ variables. Straight lines connecting paired components denote a close and reciprocal relationship between physiological variables utilized to determine the network connectance on clear and cloudy days. Each arrow above the network represents one meteorological variable influencing the strength of connection among network components. PPFD = photosynthetic photon flux density; $\mathrm{T}_{\text {air }}=$ air temperature; $\mathrm{VPD}_{\text {air }}=$ air vapor pressure deficit; $g_{\mathrm{s}}$ $=$ stomatal conductance to water vapor; $C_{\mathrm{i}} / C_{\mathrm{e}}=$ intercellular-to-external $\mathrm{CO}_{2}$ concentration ratio; $P_{\mathrm{N}}=$ net photosynthesis; $E$ = transpiration; ITE = instantaneous transpiration efficiency; $\mathrm{T}_{\text {leaf }}=$ leaf temperature. 


\section{RESULTS}

Diurnal determinations of micrometeorological conditions, leaf gas exchange, and leaf water potential on non-grafted plants were carried out as described previously (Ronquim et al., 2006). Figure 2 shows $P_{\mathrm{N}}$ as a function of PPFD in non-grafted and grafted C. arabica cultivars. Considering all cultivars and graft conditions $\mathrm{L}_{\mathrm{s}}$ averaged at $865 \mu \mathrm{mol} \mathrm{m}^{-2} \mathrm{~s}^{-1}$, but grafted Catuaí Vermelho and Obatã cultivars showed lower values of $\mathrm{L}_{\mathrm{s}}$, that is 673 and $789 \mu \mathrm{mol} \mathrm{m} \mathrm{m}^{-2} \mathrm{~s}^{-1}$, respectively. Besides, $P_{\mathrm{Nmax}}$ was around $1.2 \mu \mathrm{mol} \mathrm{m} \mathrm{m}^{-2} \mathrm{~s}^{-1}$ lower in grafted than in nongrafted plants (Figure 2). Mean diurnal values of meteorological variables (PPFD, $\mathrm{T}_{\text {air }}$, and $\mathrm{VPD}_{\text {air }}$ ) were higher on clear compared to cloudy days, especially between $0900-1500 \mathrm{~h}$, and peaked around $1300 \mathrm{~h}$ on both days (Figure 3). Despite low irradiance on a cloudy day, PPFD from $0700 \mathrm{~h}$ to $1500 \mathrm{~h}$ was within the maximum and minimum $L_{s}$ range obtained, that is 673 and $1109 \mu \mathrm{mol} \mathrm{m}^{-2}$ $\mathrm{s}^{-1}$, respectively (Figure 2).

Despite the lower PPFD, values of $P_{\mathrm{N}}, g_{\mathrm{s}}$ and $E$ were

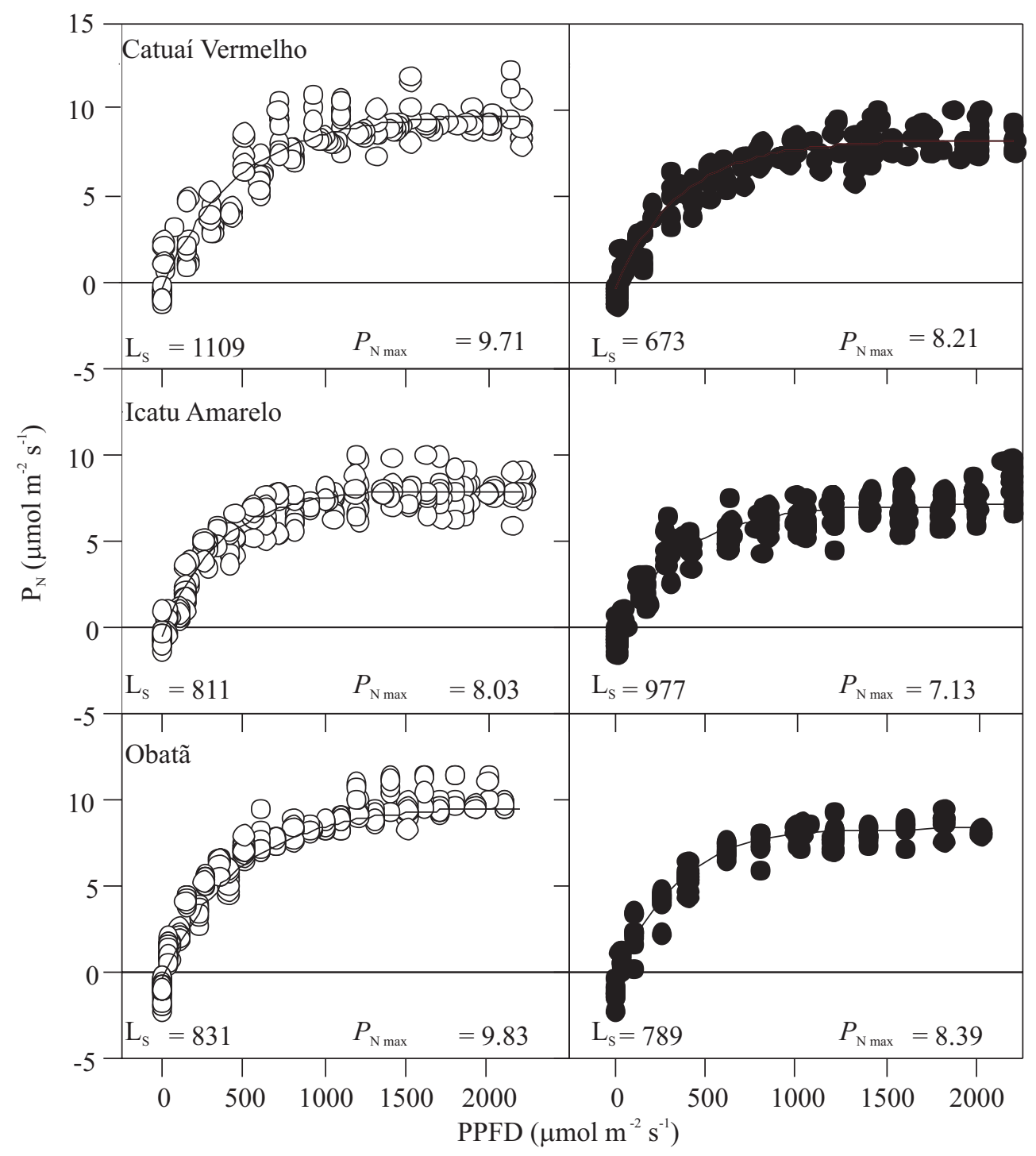

Figure 2. Net photosynthesis $\left(P_{\mathrm{N}}\right)$ as a function of photosynthetic photon flux density (PPFD) in leaves of non-grafted $(O)$ and grafted $(-)$ Coffea arabica onto C. canephora during the summer (March 2002, rainy period). Two curves were merged in each panel before adjustments. The values of maximum net photosynthesis $\left(P_{\mathrm{Nmax}}, \mu \mathrm{mol} \mathrm{m} \mathrm{s}^{-2} \mathrm{~s}^{-1}\right)$ and light saturation point $\left(\mathrm{L}_{\mathrm{s}}, \mu \mathrm{mol} \mathrm{m} \mathrm{m}^{-2} \mathrm{~s}^{-1}\right)$ are shown at the bottom of each panel. 


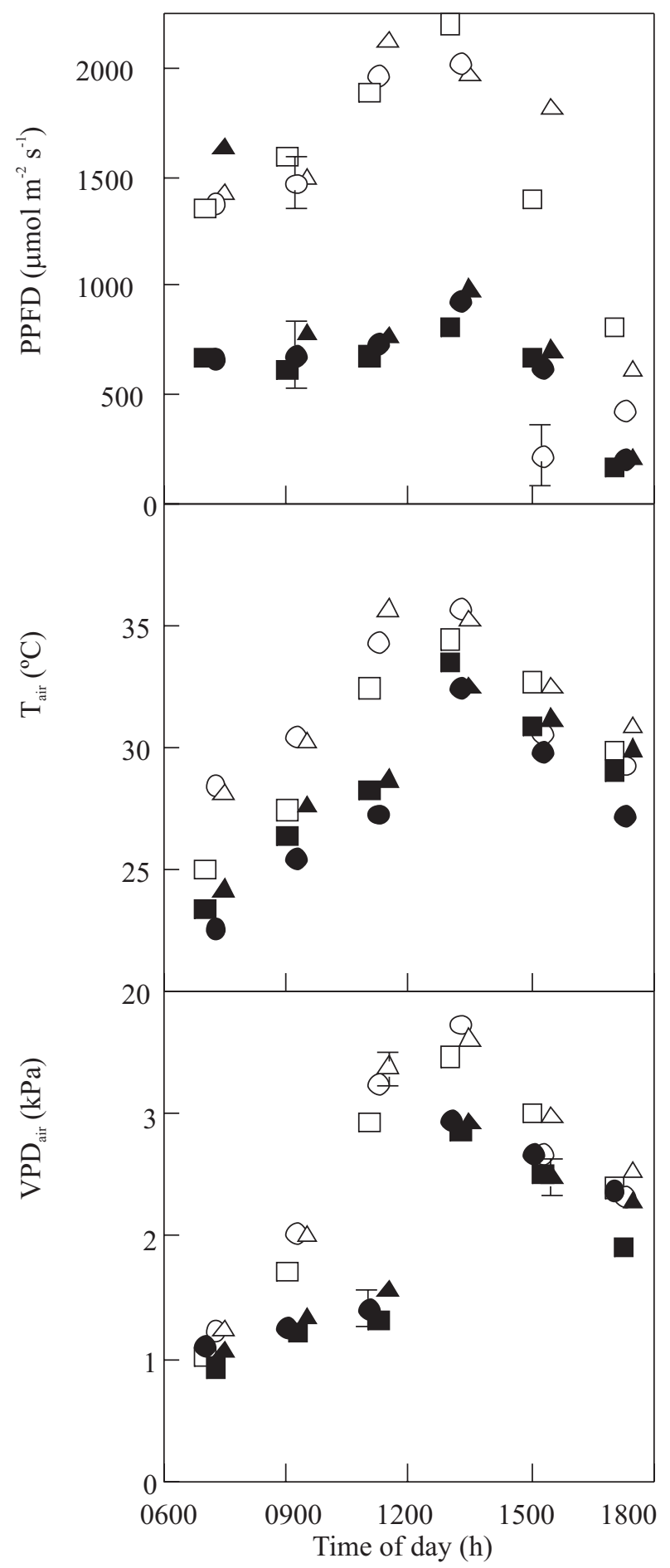

Figure 3. Diurnal courses of photosynthetic photon flux density (PPFD), air temperature $\left(\mathrm{T}_{\mathrm{air}}\right)$ and air vapor pressure deficit $\left(\mathrm{VPD}_{\text {air }}\right.$ ) on clear (open symbols) and cloudy (solid symbols) days during the rainy period. Symbol denotes mean and bar represents SE obtained for Coffea arabica cultivars Catuaí Vermelho ( $\square$, $\square$ ), Icatu Amarelo $(\bigcirc, \mathbf{O})$ and Obatã $(\triangle, \mathbf{\Delta})$ grafted on $C$. canephora. usually higher during cloudy than clear days for all cultivars (Figure 4). Leaf $\Psi_{w}$ and ITE were higher throughout cloudy compared to a clear day (Figure 5) in spite of higher corresponding values of $E$ and $g_{s}$ on a cloudy day (Figure 4). Leaf temperature was similar comparing clear and cloudy days only at the beginning and at the end of the diurnal courses (Figure 5). At noon, $\mathrm{T}_{\text {leaf }}$ was 5 to $8^{\circ} \mathrm{C}$ higher on clear compared to a cloudy day. Taking into account all cultivars concomitantly or each one individually, the mean values of $C_{i} / C_{e}$ showed similar variation during the course of clear and cloudy days (Figure 5).

Irrespective the cultivar or graft condition, $\mathrm{ADP}_{\mathrm{N}} /$ $\mathrm{PDP}_{\mathrm{N}}$ was around 3 times higher on a cloudy day (Table 1). Despite the meteorological conditions during the day, similar or higher values of $\mathrm{ADP}{ }_{\mathrm{N}} / \mathrm{PDP}{ }_{\mathrm{N}}$ were obtained for non-grafted compared to grafted cultivars, except for Catuaí Vermelho on a clear day and Obatã on a cloudy day. All plant materials showed higher autonomy (lower At values) on a cloudy day. Two patterns of behavior were discernible concerning $\mathrm{Cg}$ and At, which were higher on a clear day in non-grafted Icatu Amarelo, nongrafted Obatã, and in grafted Catuaí Vermelho. On the other hand, Cg was lower and At was higher on a clear day in non-grafted Catuaí Vermelho, grafted Icatu Amarelo, and in grafted Obatã. Considering all cultivars, both days, and graft treatments in Table $1, \mathrm{ADP}_{\mathrm{N}}$ and $\mathrm{PDP}_{\mathrm{N}}$ were not significantly correlated $(P>0.05)$ with $\mathrm{Cg}$ or At, and $\mathrm{ADP} P_{\mathrm{N}} / \mathrm{PDP}{ }_{\mathrm{N}}$ was significantly correlated $(P=$ $0.035, r=-0.610$ ) only with At. On the other hand, there was a significant correlation between $\mathrm{Cg}$ and At $(P=$ $0.024, r=0.644$ ) when pooling all cultivars, both days and graft treatments from Table 1.

Figure 6 shows the results of principal component analyses (PCA) taking into account all micrometeorological (Figure 3) and leaf physiological (Figures 4 and 5) data obtained throughout clear and cloudy days. In PCA panels on Figure 6, the pc1 axis explains more than $95 \%$ of distribution of symbols in quadrants. Vectors representing environmental and physiological variables are usually in opposite directions neighboring, respectively, the symbols of clear and cloudy days. Therefore, PPFD, $\mathrm{T}_{\text {air }}, \mathrm{VPD}_{\text {air }}$, and $\mathrm{T}_{\text {leaf }}$ vectors appeared inclined to or on the symbols representing non-grafted and grafted cultivars throughout the clear day. In contrast, $P_{\mathrm{N}}, E, g_{\mathrm{s}}, C_{\mathrm{i}} / C_{\mathrm{e}}$, ITE, 


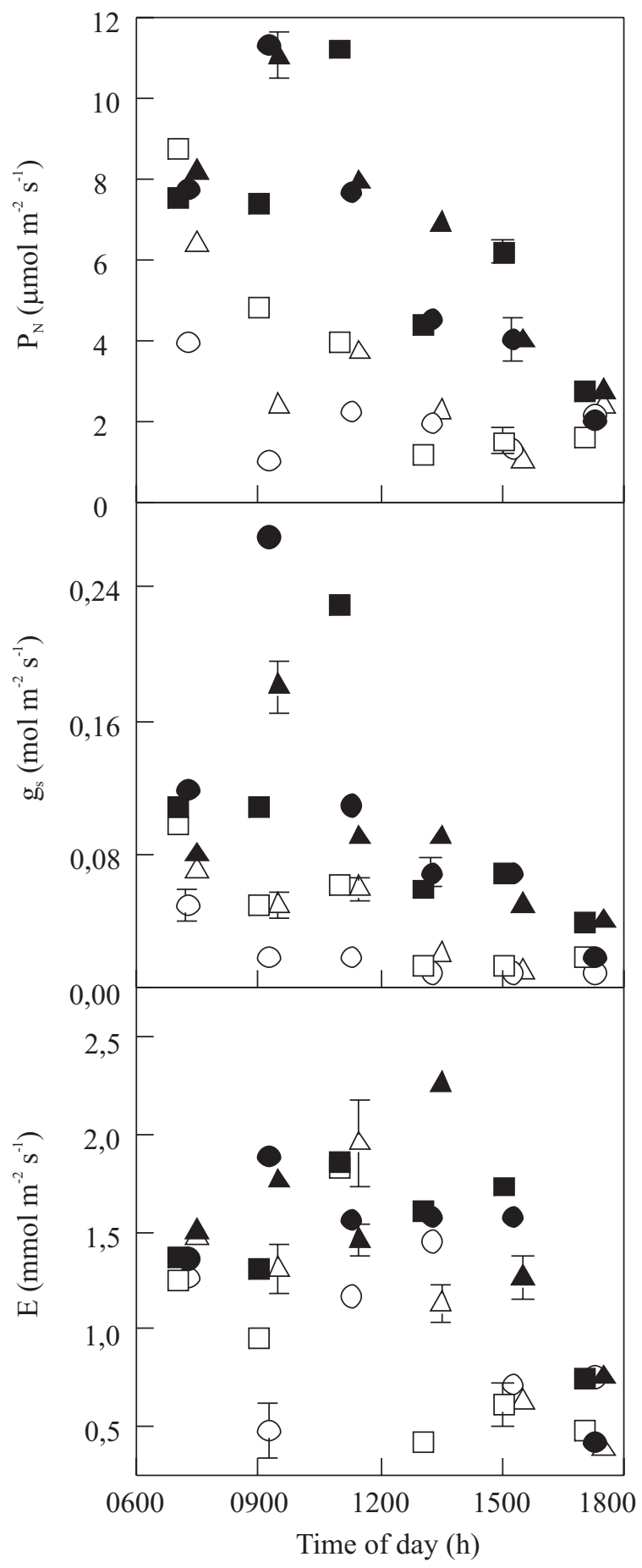

Figure 4. Leaf-atmosphere gas exchange variables measured on three Coffea arabica cultivars grafted onto C. canephora under field conditions during the rainy season on clear (open symbols) and on cloudy (solid symbols) days. Symbol denotes mean and bar represents SE obtained for cultivars Catuaí Vermelho $(\square, \boldsymbol{\square})$, Icatu Amarelo $(\bigcirc, \mathbf{\bullet})$ and Obatã $(\triangle, \mathbf{\Lambda}) \cdot P_{\mathrm{N}}=$ net photosynthesis; $g_{\mathrm{s}}=$ stomatal conductance; $E=$ leaf transpiration.

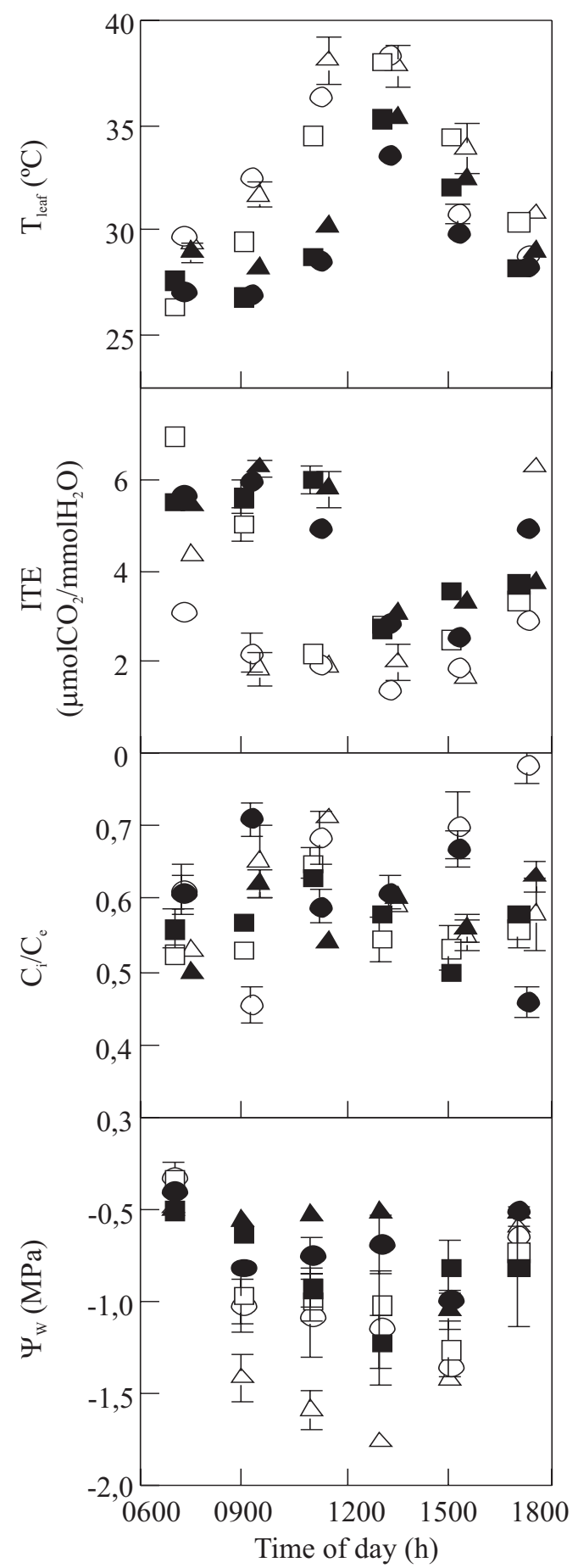

Figure 5. Leaf temperature $\left(\mathrm{T}_{\text {leaf }}\right)$, instantaneous transpiration efficiency (ITE), intercellular-to-external $\mathrm{CO}_{2}$ concentration ratio $\left(C_{\mathrm{i}} / C_{\mathrm{e}}\right)$, and leaf water potential $\left(\Psi_{\mathrm{w}}\right)$ in three Coffea arabica cultivars grafted onto $C$. canephora under field conditions during the rainy season on clear (open symbols) and cloudy (solid symbols) days. Symbol denotes mean and bar represents the SE obtained for cultivars Catuaí Vermelho $(\square, \boldsymbol{\square})$, Icatu Amarelo $(\bigcirc, \boldsymbol{\bullet})$, and Obatã $(\triangle, \mathbf{\Lambda})$. 
Table 1. Values of potential $\left(\mathrm{PDP} P_{\mathrm{N}}\right)$ and actual $\left(\mathrm{ADP} \mathrm{N}_{\mathrm{N}}\right)$ daily net photosynthesis $\left(\mathrm{mmol} \mathrm{CO}_{2} \mathrm{~m}^{-2} \mathrm{day}^{-1}\right)$ of three nongrafted and grafted Coffea arabica cultivars (Catuaí Vermelho, Icatu Amarelo and Obatã) growing under field conditions in the wet season during clear and cloudy days. Values of global connectance $(\mathrm{Cg})$ and autonomy (At) obtained throughout diurnal courses are shown.

\begin{tabular}{|c|c|c|c|c|c|c|}
\hline & \multicolumn{2}{|c|}{ Catuaí Vermelho } & \multicolumn{2}{|c|}{ Icatu Amarelo } & \multicolumn{2}{|c|}{ Obatã } \\
\hline & Clear & Cloudy & Clear & Cloudy & Clear & Cloudy \\
\hline & \multicolumn{6}{|c|}{ Non-grafted cultivars } \\
\hline $\mathrm{PDP}_{\mathrm{N}}{ }^{*}$ & 330 & 256 & 268 & 239 & 347 & 287 \\
\hline $\mathrm{ADP}_{\mathrm{N}}^{*}$ & 100 & 276 & 98 & 246 & 112 & 232 \\
\hline $\mathrm{ADP} P_{\mathrm{N}} / \mathrm{PDP}_{\mathrm{N}}{ }^{*}$ & 0.30 & 1.08 & 0.36 & 1.03 & 0.32 & 0.81 \\
\hline $\mathrm{Cg}$ & 0.58 & 0.65 & 1.04 & 0.51 & 0.63 & 0.46 \\
\hline \multirow[t]{2}{*}{ At } & 0.93 & 0.75 & 0.91 & 0.68 & 0.71 & 0.58 \\
\hline & \multicolumn{6}{|c|}{ Grafted cultivars } \\
\hline $\mathrm{PDP}_{\mathrm{N}}$ & 289 & 232 & 249 & 237 & 287 & 247 \\
\hline $\mathrm{ADP} P_{\mathrm{N}}$ & 121 & 248 & 71 & 234 & 99 & 254 \\
\hline $\mathrm{ADP} P_{\mathrm{N}} / \mathrm{PD} P_{\mathrm{N}}$ & 0.42 & 1.07 & 0.28 & 0.99 & 0.34 & 1.03 \\
\hline Cg & 0.74 & 0.60 & 0.57 & 0.66 & 0.52 & 0.53 \\
\hline At & 0.86 & 0.69 & 0.70 & 0.66 & 0.75 & 0.57 \\
\hline
\end{tabular}

*Obtained by Ronquim et al. (2006) on non-grafted cultivars.

and $\Psi_{w}$ vectors tended to incline to symbols representing cultivars during a cloudy day (Figure 6). There is an unmistakable separation between symbols representing distinct days from early morning up to the end of the afternoon, especially around midday. In addition, the grouping of symbols for a clear day is more pronounced than for a cloudy day, especially under high PPFD at 1100 $\mathrm{h}$ and $1300 \mathrm{~h}$.

\section{DISCUSSION}

On a clear day, the decrease in $P_{\mathrm{N}}$ after midday may be due to stomatal changes, since the values of $g_{\mathrm{s}}$ were low during that period. Besides, high values of PPFD indicated that low $P_{\mathrm{N}}$ observed during the clear day could be due to photoinhibition (Ronquim et al., 2006). In addition to high PPFD, $\mathrm{T}_{\text {leaf }}$ was higher than $30^{\circ} \mathrm{C}$ on a clear day from $1200 \mathrm{~h}$ up to $1500 \mathrm{~h}$, when $\Psi_{\mathrm{w}}$ was low. Therefore, $P_{\mathrm{N}}$ depression around midday could be a consequence of adverse photochemical, biophysical (low $g_{\mathrm{s}}$ and $\Psi_{\mathrm{w}}$ ), and thermal (high $\mathrm{T}_{\text {leaf }}$ ) leaf circumstances provoked by high PPFD, $\mathrm{T}_{\text {air }}$ and $\mathrm{VPD}_{\text {air }}$. Consequently, irrespective the cultivar or graft treatment, $\mathrm{ADP}_{\mathrm{N}}$ and $\mathrm{ADP}_{\mathrm{N}} / \mathrm{PDP} \mathrm{N}_{\mathrm{N}}$ values were lower on a clear compared to cloudy day.

On the other hand, the close connection with environment (low autonomy) found for all cultivars and graft treatments on a clear day indicates high synchronization between leaf physiology and meteorological conditions. This implies an increasing leaf physiological vulnerability since natural populations of C. arabica were adapted to understory conditions in highland forests. Therefore, the synchronization between leaf physiology and high PPFD, $\mathrm{T}_{\text {air, }}$ and $\mathrm{VPD}_{\text {air }}$ seems particularly injurious to photosynthetic processes in $C$. arabica on a clear day, as further supported by the significant correlation between At and $\operatorname{ADP} P_{N} / P D P_{N}$. Influences of At on carbon balance of $C$. arabica could be even more evident in the dry season, when water stress occurs aboveground and belowground simultaneously.

A graft on C. canephora is probably the better condition to retain low At, because grafted cultivars showed lower At than non-grafted on clear and cloudy days. One exception was Obatã, that presented higher At in grafted compared to non-grafted plants on a clear day. In fact, Obatã seems the most sensitive cultivar to environmental stresses such as high PPFD, $\mathrm{T}_{\text {air, }}$ and $\mathrm{VPD}_{\text {air }}$. Non-grafted Obatã could not attain similar values comparing $\mathrm{ADP}_{\mathrm{N}}$ and $\mathrm{PD} P_{\mathrm{N}}$ even on a cloudy day. Besides, grafted Obatã was unable to modulate the strength of connection between leaf gas exchange- $\Psi_{w}$ variables, showing similar Cg values on both cloudy and clear days. In addition, At was virtually the same 


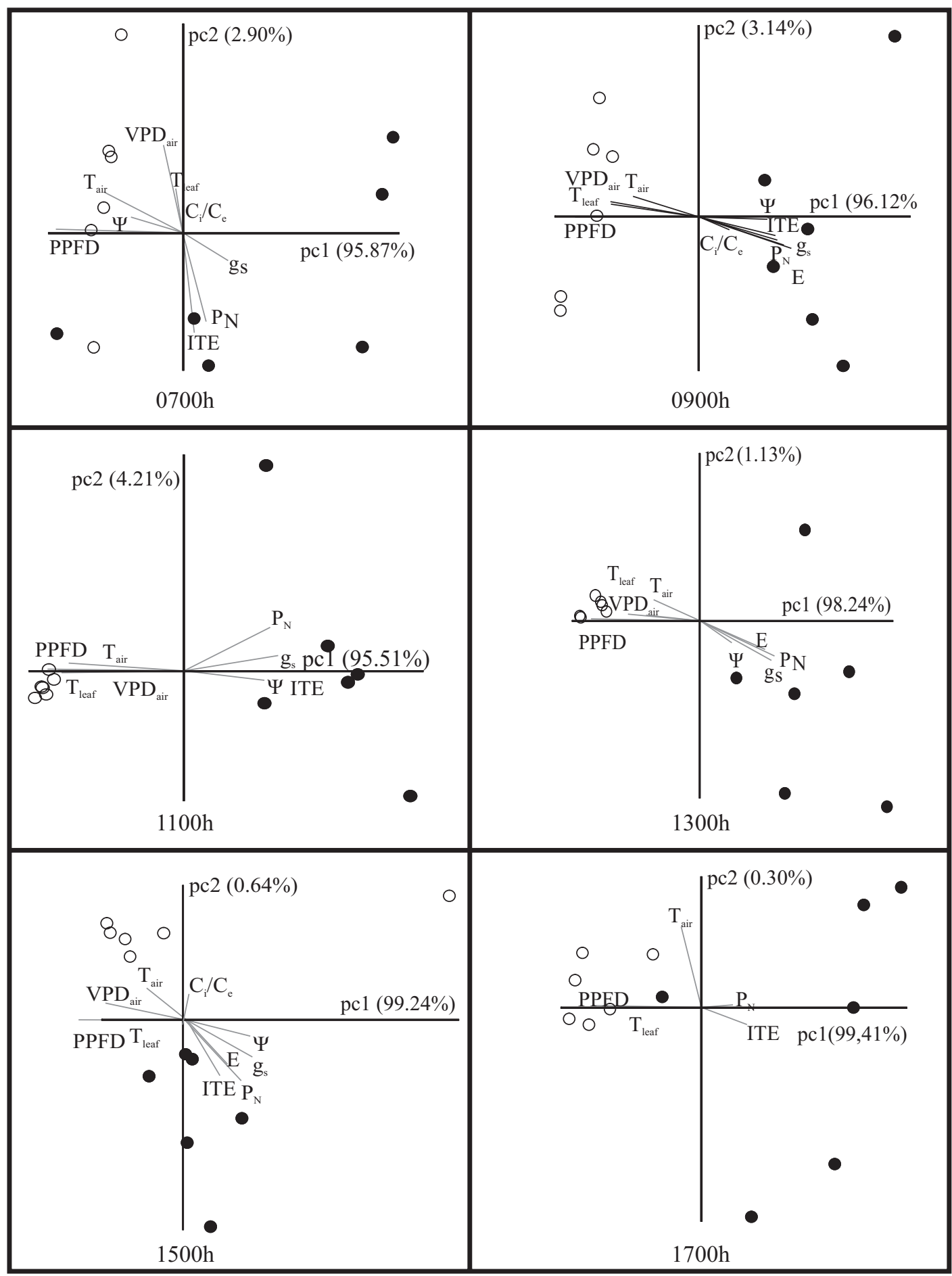

Figure 6. Principal component analysis of leaf gas exchange and leaf water potential ( $\left.\Psi_{w}\right)$ obtained during diurnal courses in three Coffea arabica cultivars. Each panel represents one time of the day. Clear and cloudy days are represented by open $(\bigcirc)$ and solid $(\bigcirc)$ symbols, respectively. Each symbol indicates one cultivar irrespective of treatment (non-grafted or grafted). Grey straight lines (vectors) represent the most important environmental or physiological variables. $\mathrm{PPFD}=$ photosynthetic photon flux density; $\mathrm{VPD}_{\text {air }}=$ air vapor pressure deficit; $\mathrm{T}_{\text {air }}=$ air temperature; $\mathrm{T}_{\text {leaf }}=$ leaf temperature; $P_{\mathrm{N}}=$ net photosynthesis; $g_{\mathrm{s}}=$ stomatal conductance; $E=$ leaf transpiration; ITE = instantaneous transpiration efficiency; $C_{\mathrm{i}} / C_{\mathrm{e}}=$ intercellular-to-external $\mathrm{CO}_{2}$ concentration ratio. 
comparing grafted and non-grafted plants of Obatã on corresponding days. The cultivar Catuaí Vermelho showed the opposite behavior in relation to Obatã, especially when grafted. Comparing grafted with nongrafted plants of Catuaí Vermelho on a clear day, the former treatment showed higher $\mathrm{ADP}{ }_{\mathrm{N}} / \mathrm{PD} P_{\mathrm{N}}$. In addition, grafted Catuaí Vermelho showed lower At and was capable of modulating $\mathrm{Cg}$ to a greater extent on clear and cloudy days than non-grafted plants.

Global connectance did not show predictable behavior according to cultivar, graft treatment or day condition. It indicates that the force of connection among leaf physiological variables could decrease from cloudy to clear days avoiding breakdown propagation, or it could increase leading to the leaf gas exchange- $Y_{w}$ network becoming more responsive. This kind of plasticity in C. arabica probably is important to modulate the leaf gas exchange- $Y_{w}$ network taking into account the kind of shoot (cultivar) and the type of root system (non-grafted or grafted condition). However, At and $C g$ were linked for $C$. arabica cultivars, since these parameters were significantly correlated considering nongrafted and grafted plants.

Symbols in PCA representing non-grafted and grafted cultivars are more grouped during the course of the clear day, indicating that leaf physiological variables showed less diurnal variation among cultivars under high PPFD, $\mathrm{T}_{\text {air, }}$ and $\mathrm{VPD}_{\text {air }}$. This suggests that stressful meteorological conditions are determining the close grouping configuration during a clear day, when At values were higher in all cultivars and grafting treatments. Therefore, increasing strength of connections among leaf physiological and meteorological variables results in minor differences among cultivars in relation to leaf gas exchange and $\Psi_{w}$ behavior, which corroborate the lower autonomy found for clear compared to cloudy days.

Ronquim et al. (2006) utilized only one leaf physiological variable $\left(P_{\mathrm{N}}\right)$ to infer that high PPFD, $\mathrm{T}_{\text {air }}$, and $\mathrm{VPD}_{\text {air }}$ provoked $P_{\mathrm{N}}$ midday depression in C. arabica. In the present study, using autonomy, network connectance and PCA, it was possible to demonstrate that $P_{\mathrm{N}}$ decreases were accompanied by low plant autonomy and low variation of leaf physiological variables. In addition, PCA confirms the strong influence of daily meteorological conditions through PPFD, $\mathrm{T}_{\text {air }}$ and $V D_{\text {air }}$ vectors being in opposition to leaf physiological vectors. Autonomy, connectance and PCA analysis in $C$. arabica were appropriate to discriminate the impact of stress factors and the responses of each cultivar and grafting treatment in the field, revealing the leaf gas exchange- $\Psi_{w}$ network modulation that underlies the plant-environmental relationship. Therefore, with integrated daily $P_{\mathrm{N}}$, At, Cg and PCA, it was possible to show how and to what extent grafted and non-grafted $C$. arabica were able to overcome high irradiance, air temperature and evaporative demand throughout the day.

Acknowledgements: Authors gratefully acknowledge the scholarships from CNPq to LHGCB, CHBA and GMS, and the scholarship from FAPESP to PN.

\section{REFERENCES}

Amzallag GN (2001) Data analysis in plant physiology: are we missing the reality? Plant Cell Environ. 24:881-890.

Carelli MLC, Fahl JI, Trivelin PCO, Voltan RBQ (1999) Carbon isotope discrimination and gas exchange in coffee species grown under different irradiance regimes. Rev. Bras. Fisiol. Veg. 11:63-68.

Costa WM, Gonçalves W, Fazuoli LC (1991) Produção do café Mundo Novo em porta-enxertos de Coffea canephora em área infestada com Meloidogyne incognita raça 1. Nematol. Bras. 15:43-50.

Fahl JI, Carelli MLC, Menezes HC, Gallo PB, Trivelin PCO (2001) Gas exchange, growth, yield and beverage quality of $C$. arabica cultivars grafted on to $C$. canephora and C. congensis. Exp. Agric. 37:241-252.

Kikusawa K, Shirskawa H, Suzuki M, Umeki K (2004) Mean labor time of a leaf. Ecol. Res. 19:365-374.

Manly BJF (1994) Multivariate Statistical Methods. Chapman \& Hall, London.

Nogueira A, Martinez CA, Ferreira LL, Prado CHBA (2004) Photosynthesis and water use efficiency in twenty tropical tree species of differing succession status in a Brazilian reforestation. Photosynthetica 42:351-356.

Prado CHBA, Moraes JAPV (1997) Photosynthetic capacity and specific leaf mass in twenty woody species of Cerrado vegetation under field conditions. Photosynthetica 33:103-112.

Prado CHBA, Wenhui Z, Rojas MHC, Souza GM (2004) Seasonal leaf gas exchange and water potential in a woody cerrado species community. Braz. J. Plant Physiol. 16:7-16. 
Ronquim JC, Prado CHBA, Novaes P, Fahl JI, Ronquim CC (2006) Carbon gain in Coffea arabica L. during clear and cloudy days in wet season. Exp. Agric. 22:147-164. Souza GM, Ribeiro RV, Santos MG, Ribeiro HL, Oliveira RF (2004) Functional groups of forest succession as dissipative structures: an applied study. Braz. J. Biol. 64:707-718.
Souza GM, Ribeiro RV, Oliveira RF, Machado EC (2005) Network connectance and autonomy analyses of the photosynthetic apparatus in tropical tree species from different successional groups under contrasting irradiance conditions. Rev. Bras. Bot. 28:47-59.

Zar JH (1999) Biostatistical Analysis. Prentice-Hall, New Jersey. 